\title{
Influence of Different Levels of Fertility and Plant Geometry on Growth and Yield of $B t$ Cotton
}

\author{
Amit Singh", M. L. Khichar, Ram Niwas, Sagar Kumar, Divesh, Mamta and Rahul \\ Department of Agricultural Meteorology, Chaudhary Charan Singh Haryana Agricultural \\ University, Hisar-125 004, India \\ *Corresponding author
}

\begin{abstract}
A B S T R A C T
Keywords

Yield, Plant height, LAI and Dry matter

Article Info

Accepted:

04 August 2020

Available Online:

10 September 2020

A field experiment was carried out during the kharif season of 2015 at the research farm of Department of Genetics \& Plant Breeding, CCS HAU, Hisar (Lat. 29 ${ }^{\circ} 10^{\prime}$ N, Log. $75^{\circ} 46^{\prime}$ $\mathrm{E}$ and $215.2 \mathrm{~m} \mathrm{msl}$ ) to study the effect of fertility and plant spacing on plant height, dry matter accumulation, LAI and yield of the $B t$ cotton. The experiment was laid out in splitsplit plot design with 3 varieties ( $\mathrm{RCH} 602$, RCH 650 and Bunty) in main plot, 3 plant geometries $(67.5 \times 75 \mathrm{~cm}, 67.5 \times 60 \mathrm{~cm}$ and $67.5 \times 45 \mathrm{~cm})$ in sub plot and 3 fertilizer levels (Recommended Dose of NPK $(\mathrm{RDF}=\mathrm{N}: \mathrm{P}: \mathrm{K}: 175: 60: 60 \mathrm{~kg} / \mathrm{ha}), 125$ per cent of Recommended Dose of NPK and 150 per cent of Recommended Dose of NPK) in sub-sub plot with 3 replications. RCH 602 attained maximum plant height, dry matter accumulation, LAI and yield (1248.7 kg ha ${ }^{-1}$ ) followed by RCH 650 and Bunty. Maximum plant height and LAI at 120 days after sowing were recorded in plant geometry $67.5 \times 45$ $\mathrm{cm}$, whereas the plant geometry $67.5 \times 75 \mathrm{~cm}$ have maximum dry matter accumulation and yield $\left(1120.7 \mathrm{~kg} \mathrm{ha}^{-1}\right)$. Maximum plant height, dry matter accumulation and LAI (at 120 days after sowing) were found significantly higher in RDF 150 per cent, however the maximum yield was recorded with RDF 125 per cent $\left(1094.3 \mathrm{~kg} \mathrm{ha}^{-1}\right)$.
\end{abstract}

\section{Introduction}

Cotton (Gossypium hirsutum L.) known as "The king of fibre" and the leading fibre crop of the India. Cotton is an important raw material for the Indian textile industry and an important cash crop of the country. The cotton crop also called 'white gold' enjoys a premier position amongst all commercial crops in India. In India, the cotton productivity is very low as compared to other countries. But after the launching of
"Technology Mission on Cotton" by Government of India in February 2000, the significant achievements have been made in increasing yield and productivity through development of high yielding varieties, better farm management practices, increased area under cultivation of $B t$ cotton hybrids. After introduction of transgenic $B t$ hybrid cotton in India, the productivity of cotton has increased substantially from 303 to $561 \mathrm{~kg} / \mathrm{ha}$ within a span of seven years (Tayade et al., 2011). 
Among the nutrients nitrogen $(\mathrm{N})$ is required most consistently and in larger amounts than the other nutrients for production of cotton (Hou et al., 2007). Nitrogen plays an essential role in canopy area development and photosynthesis (Wullschleger and Oosterhuis, 1990). Nitrogen also increased the cotton yield (Bondada et al., 1996; Boquet et al., 1993). Potassium is important in maintaining the osmotic potential and water uptake during fiber development and a shortage will result in lower yields (Oosterhuis, 2001). Plant density is also an important factor that influences the cotton yield. Maximum yield is achieved at optimum plant density which depends upon environmental condition, cropping system and cultivar (Bridge et al., 1973; El-Shinnawy and Ghaly, 1985; Halemani and Hallikeri, 2002). However, farmers are adopting various plant geometries with wider row spacings as well as closer plant spacings. As $B t$ cotton cultivation has resulted in early setting of bolls, ultimately it requires more nutrients. Therefore, the present study was carried out to know the effect of spacing and fertility levels growth and yield of $B t$ cotton.

\section{Materials and Methods}

A field experiment was conducted during kharif seasons of 2015-16 at the Department of Genetics \& Plant Breeding, CCS HAU, Hisar (Lat 290 10' N, Long 750 46' E and $215.2 \mathrm{~m} \mathrm{msl}$ ). The experiment was conducted in split-split plot design with three replications. The experiment consist of three varieties viz. $\mathrm{V}_{1}=\mathrm{RCH} 602, \mathrm{~V}_{2}=\mathrm{RCH} 650$ and $\mathrm{V}_{3}=$ Bunty were kept in main plots while three spacing viz. $\mathrm{S}_{1}=67.5 \mathrm{~cm} \times 45 \mathrm{~cm}$, $\mathrm{S}_{2}=67.5 \mathrm{~cm} \times 60 \mathrm{~cm}$ and $\mathrm{S}_{3}=67.5 \mathrm{~cm} \times 75$ $\mathrm{cm}$ with three fertilizer levels viz. $\mathrm{F}_{1}=\mathrm{RDF}$, $\mathrm{F}_{2}=125 \%$ of $\mathrm{RDF}$ and $\mathrm{F}_{3}=150 \%$ of $\mathrm{RDF}$ application of the recommended dose were kept in subplots. Recommended dose of fertilizer is (RDF) N:P:K=175:60:60 kg ha ${ }^{-1}$.

\section{Plant height (cm)}

The plant height in centimeters was recorded by measuring the height from ground level to the tip of the plant at 30, 60, 90, 120 and 150 days after sowing.

\section{Leaf area index (LAI)}

Three plants were uprooted from each plot and their leaves were used for measuring leaf area per plant $\left(\mathrm{cm}^{2}\right)$ with the help of leaf area meter (LI-3000 Leaf Area Meter, LICOR Ltd., Nebraska, USA) at 30, 60, 90, 120 and 150 days after sowing:

$L A I=\frac{\text { Total green leaf area of plant }\left(\mathrm{cm}^{2}\right)}{\text { Total groung area }\left(\mathrm{cm}^{2}\right)}$

\section{Dry matter (g plant ${ }^{-1}$ )}

Three plants per plot were harvested from the ground level. To know the change indry matter accumulation at 30,60, 90, 120 and 150 days after sowing. The samples were first air dried and then oven dried at a temperature of $70{ }^{\circ} \mathrm{C}$ till constant weight was obtained. Dry weight was recorded and was expressed on per plant basis.

\section{Grain yield ( $\left.\mathrm{kg} \mathrm{ha}^{-1}\right)$}

Net area from each plot was harvested. The seed cotton yield from net plot was recorded and computed as seed cotton yield $\mathrm{kg} \mathrm{ha}^{-1}$.

\section{Results and Discussion}

\section{Plant height (cm)}

Data presented in the table lindicated that the different treatments had a major effect on the plant height. The plant height recorded at various intervals revealed that plant height increase with the progression of crop growth till maturity. The cultivar RCH 602 attain 
maximum plant height at all the recorded intervals i.e. 30, 60, 90, 120 and 150 days after sowing $38.2 \mathrm{~cm}, 96.4 \mathrm{~cm}, 150.0 \mathrm{~cm}$, $152.6 \mathrm{~cm}$ and $154.6 \mathrm{~cm}$, respectively tailed by the RCH 650 and Bunty.

Different plant spacing affect the plant height significantly except at 30 and 60 days after sowing where the plant height was significantly at par with each of the plant spacing. At 30 and 60 days after sowing the plant height among the spacing remain at par, after 90 days onward the narrow plant spacing $(67.5 \times 45 \mathrm{~cm})$ attained higher plant height viz. $139.2 \mathrm{~cm}, 147.1 \mathrm{~cm}, 149.1 \mathrm{~cm}$ at 90,120 and 150 days after sowing, respectively in comparison to the wider plant spacings. At 120 days after sowing, plant spacing $67.5 \times$ $60 \mathrm{~cm}$ and $67.5 \times 75 \mathrm{~cm}$ attain plant height $147.3 \mathrm{~cm}, 141.9 \mathrm{~cm}$, respectively. This indicated that plant height decrease with the increase in the plant spacings. Prasad et al., (2000); Nehra and Chandra (2001); Nehra and Kumawat (2003) and Kaur and Brar (2005) reported that plant height decrease in wider plant spacing as compared to the narrow plant spacings.

Fertilizer levels had a positive effect on the plant height, data indicated that plant height increased with the increase in fertilizer levels from RDF to 150 per cent of RDF. And maximum plant height at all the intervals was appeared with the fertilizer level 150 per centof RDF and at 150 days after sowing the plant height was $148.4 \mathrm{~cm}$, which was higher than the 125 per cent RDF $(145.7 \mathrm{~cm})$ and RDF (144.2 cm). Sagarka et al., (2002); Thokale et al., (2004) and Ram and Giri (2006) also reported alike results that plant height increase with an increase in fertilizer levels.

Table.1 Effect of plant spacing and fertilizer levels on plant height $(\mathrm{cm})$ of cotton crop recorded at different intervals

\begin{tabular}{|l|c|c|c|c|c|}
\hline \multicolumn{5}{|c|}{ Plant height (cm) } \\
\hline TREATMENTS & 30 DAS & 60DAS & 90DAS & 120 DAS & 150 DAS \\
\hline Cultivars & & & & & \\
\hline RCH 602 & 38.2 & 96.4 & 150.0 & 152.6 & 154.6 \\
\hline RCH 650 & 37.2 & 88.8 & 134.9 & 149.1 & 150.8 \\
\hline Bunty & 34.7 & 83.8 & 119.9 & 130.7 & 133.0 \\
\hline CD at 5\% & 0.2 & 1.3 & 1.2 & 1.3 & 0.7 \\
\hline Plant spacing & & & & & \\
\hline 67.5 x 45 cm & 36.8 & 90.8 & 139.2 & 147.1 & 149.1 \\
\hline 67.5 $\times \mathbf{6 0}$ cm & 36.8 & 89.2 & 137.5 & 145.4 & 147.3 \\
\hline 67.5 $\times$ 75 cm & 36.5 & 89.1 & 128.1 & 139.8 & 141.9 \\
\hline CD at 5\% & 0.1 & 0.4 & 0.3 & 0.4 & 0.1 \\
\hline Fertilizer levels & & & & & \\
\hline RDF & 35.7 & 88.5 & 133.4 & 142.1 & 144.2 \\
\hline $\mathbf{1 2 5 \%}$ of RDF & 36.2 & 89.6 & 134.5 & 144.2 & 145.7 \\
\hline $\mathbf{1 5 0} \%$ of RDF & 38.2 & 90.9 & 136.9 & 146.1 & 148.4 \\
\hline CD at 5\% & 0.1 & 0.0 & 0.1 & 0.1 & 0.1 \\
\hline
\end{tabular}

RDF $=$ Recommended Dose of Fertilizer

DAS= Days After Sowing 
Table.2 Effect of different plant spacing and fertilizer levels on dry matter accumulation $\left(\mathrm{g}_{\text {plant }}{ }^{-1}\right)$

\begin{tabular}{|l|c|c|c|c|c|}
\hline \multicolumn{5}{|c|}{ Dry matter $\left(\mathbf{g ~ p l a n t ~}^{-1}\right)$} \\
\hline Treatments & 30 DAS & 60 DAS & 90 DAS & 120 DAS & 150 DAS \\
\hline Cultivars & & & & & \\
\hline RCH 602 & 9.5 & 62.5 & 260.9 & 372.3 & 452.5 \\
\hline RCH 650 & 9.4 & 57.2 & 225.4 & 278.6 & 323.8 \\
\hline Bunty & 8.9 & 56.7 & 203.5 & 226.2 & 320.3 \\
\hline CD at 5\% & 0.01 & 0.14 & 0.14 & 0.18 & 0.27 \\
\hline Plant spacing & & & & & \\
\hline $\mathbf{6 7 . 5} \times \mathbf{4 5}$ cm & 8.2 & 55.2 & 201.6 & 267.0 & 340.4 \\
\hline $\mathbf{6 7 . 5} \times \mathbf{6 0}$ cm & 9.1 & 58.3 & 224.8 & 285.5 & 371.6 \\
\hline $\mathbf{6 7 . 5} \times \mathbf{7 5}$ cm & 10.6 & 62.9 & 263.3 & 324.6 & 384.5 \\
\hline CD at 5\% & 0.01 & 0.24 & 0.24 & 0.03 & 0.17 \\
\hline Fertilizer levels & & & & & \\
\hline RDF & 8.7 & 55.1 & 197.2 & 273.4 & 357.6 \\
\hline $\mathbf{1 2 5 \%}$ of RDF & 8.8 & 59.9 & 236.5 & 300.0 & 362.6 \\
\hline $\mathbf{1 5 0 \%}$ of RDF & 10.2 & 61.4 & 255.9 & 303.6 & 376.3 \\
\hline CD at 5\% & 0.01 & 0.23 & 0.23 & 0.02 & 0.21 \\
\hline
\end{tabular}

$\mathrm{RDF}=$ Recommended Dose of Fertilizer

DAS= Days After Sowing

Table.3 Leaf area index recorded at different stages of crop growth, as affected by plant spacing and fertilizer levels

\begin{tabular}{|c|c|c|c|c|c|}
\hline \multicolumn{6}{|c|}{ Leaf area index (LAI) } \\
\hline & 30 DAS & 60 DAS & 90 DAS & 120 DAS & 150 DAS \\
\hline \multicolumn{6}{|l|}{ Cultivars } \\
\hline RCH 602 & 0.3 & 1.3 & 3.5 & 6.2 & 3.2 \\
\hline RCH 650 & 0.2 & 1.3 & 3.3 & 4.9 & 2.0 \\
\hline Bunty & 0.2 & 1.3 & 3.2 & 4.4 & 1.8 \\
\hline CD at $5 \%$ & 0.020 & 0.011 & 0.004 & 0.083 & 0.003 \\
\hline \multicolumn{6}{|l|}{ Plant spacing } \\
\hline $67.5 \times 45 \mathrm{~cm}$ & 0.3 & 1.4 & 3.6 & 5.6 & 2.7 \\
\hline $67.5 \times 60 \mathrm{~cm}$ & 0.3 & 1.3 & 3.3 & 5.5 & 2.7 \\
\hline $67.5 \times 75 \mathrm{~cm}$ & 0.3 & 1.3 & 3.2 & 5.3 & 2.4 \\
\hline CD at $5 \%$ & 0.016 & 0.013 & 0.002 & 0.066 & 0.001 \\
\hline \multicolumn{6}{|l|}{ Fretilizer levels } \\
\hline RDF & 0.2 & 1.3 & 3.1 & 5.0 & 1.9 \\
\hline $125 \%$ of RDF & 0.3 & 1.3 & 3.4 & 5.1 & 2.3 \\
\hline $150 \%$ of RDF & 0.3 & 1.3 & 3.5 & 5.3 & 2.9 \\
\hline CD at $5 \%$ & 0.015 & 0.019 & 0.001 & 0.061 & 0.001 \\
\hline
\end{tabular}


Table.4 Effect of plant spacing and fertilizer levels on cotton yield

\begin{tabular}{|l|c|}
\hline TREATMENTS & $\begin{array}{c}\text { Seed cotton } \\
\text { Yield }\left(\mathbf{K g ~ h}^{\mathbf{- 1}}\right)\end{array}$ \\
\hline Cultivars & \\
\hline RCH 602 & 1248.7 \\
\hline RCH 650 & 1080.1 \\
\hline Bunty & 868.7 \\
\hline CD at 5\% & 81.1 \\
\hline Plantspacing & \\
\hline $\mathbf{6 7 . 5} \times \mathbf{4 5} \mathbf{~ c m}$ & 998.8 \\
\hline $\mathbf{6 7 . 5} \times \mathbf{6 0} \mathbf{~ c m}$ & 1078.0 \\
\hline $\mathbf{6 7 . 5} \times \mathbf{7 5} \mathbf{~ c m}$ & 1120.7 \\
\hline CD at 5\% & 81.1 \\
\hline Fertilizerlevels & 1017.1 \\
\hline RDF & 1094.3 \\
\hline $\mathbf{1 2 5 \%}$ of RDF & 1086.2 \\
\hline $\mathbf{1 5 0} \%$ of RDF & $\mathrm{NS}$ \\
\hline CD at 5\% & \\
\hline
\end{tabular}

RDF $=$ Recommended Dose of Fertilizer

DAS $=$ Days after Sowing

\section{Dry matter accumulation $\left(\mathrm{g}\right.$ plant $\left.{ }^{-1}\right)$}

Data showed in table 2 reviled that the dry matter accumulation per plant had really influenced by the different levels of plant spacing and fertilizer levels at various intervals of crop growth. Among the varieties the $\mathrm{cv}$. RCH 602 accumulated the maximum dry matter per plant at the various intervals viz. $60,90,120$ and 150 days after sowing $62.5 \mathrm{~g}, 260.9 \mathrm{~g}, 372.3 \mathrm{~g}$ and $452.5 \mathrm{~g}$, respectively except at 30 days after sowing where RCH $602(9.5 \mathrm{~g})$ was statistically at par with $\mathrm{RCH} \quad 650 \quad(9.4$ g). Plant spacing significantly affect the dry matter accumulation. Wider plant spacing $67.5 \times 75$ $\mathrm{cm}$ accumulated more dry matter as compared to other two narrow plant spacings at all the recorded growth intervals at 30,60, 90, 120 and 150 days after sowing $10.6 \mathrm{~g}, 62.9 \mathrm{~g}$, $263.3 \mathrm{~g}, 324.6 \mathrm{~g}$ and $384.5 \mathrm{~g}$, respectively followed by $67.5 \times 60 \mathrm{~cm}$ and $67.5 \times 45 \mathrm{~cm}$. The present results similar with those of
Bhalerao et al., (2010) and Kumar et al., (2011) that the dry matter accumulated in wider plant spacing was more than that of the narrow plant spacing. Data showed that the there was an increase in dry matter accumulation with the increase in the fertility levels. 150 per cent of RDF accumulated maximum dry matter than the other two fertility levels. Dry matter accumulated by the 150 per centof RDF, 125 per centof RDF and $\mathrm{RDF}$ at 150 days after sowing were $376.3 \mathrm{~g}$, $362.6 \mathrm{~g}$ and $357.6 \mathrm{~g}$, respectively. Bhalerao et al., (2010) and Paslawar et al., (2014) also reported that there was an increase in the dry matter accumulation with increased fertilizer levels as compared to the lower levels of fertilizers.

\section{Leaf Area Index}

Data in table 3 showed that there was a significant effect of all the treatments on LAI. Among all the treatments LAI increase upto 
120 days after sowing after that a decrease in LAI was noted. LAI reached its peak value at 120 days after sowing and then decline after that due to leaf senescence. Variety RCH 602 attained maximum LAI (6.2) at 120 days after sowing followed by RCH 650 and Bunty were 4.9 and 4.4 , respectively.

Plant spacing greatly influenced LAI, among the plant spacing the narrow plant spacing $67.5 \times 45 \mathrm{~cm}$ have the maximum LAI (5.6) at 120 days after sowing followed by $67.5 \times 60$ $\mathrm{cm}$ and $67.5 \times 75 \mathrm{~cm}$ were 5.5 and 5.3 at 120 days after sowing, respectively.

Darawsheh et al., (2009) also reported that the narrow plant spacing have higher LAI in comparison to wider plant spacing. LAI increase with the increase in fertilizer levels and attain maximum at 120 days after sowing. Higher LAI (5.3) noticed with the 150 per cent of RDF followed by other two fertilizer levels viz. 125 per cent of RDF and RDF were 5.1 and 5.0, respectively. Felix et al., (2003) reported that LAI increase with increase in fertilizer levels.

\section{Seed cotton yield ( $\left.\mathrm{kg} \mathrm{ha}^{-1}\right)$}

The observed data clearly shows that the seed cotton yield $\mathrm{kg} \mathrm{ha}^{-1}$ was significantly influenced by different treatments. Among the varieties cv. RCH 602 have the maximum seed cotton yield $\mathrm{kg} \mathrm{ha}{ }^{-1}\left(1248.7 \mathrm{~kg} \mathrm{ha}^{-1}\right)$ followed by RCH 650 and Bunty were 1080.1 $\mathrm{kg} \mathrm{ha}^{-1}$ and $868.7 \mathrm{~kg} \mathrm{ha}^{-1}$, respectively.

The highest seed cotton yield $\mathrm{kg} \mathrm{ha}^{-1}$ (1120.76 $\mathrm{kg} \mathrm{ha}{ }^{-1}$ ) was observed under wider plant spacing $(67.5 \mathrm{~cm} \times 75 \mathrm{~cm})$ than the other plant spacing, However seed cotton yield $\mathrm{kg}$ $\mathrm{ha}^{-1}\left(998.83 \mathrm{~kg} \mathrm{ha}^{-1}\right)$ was found lowest with narrow plant spacing of $67.5 \mathrm{~cm} \mathrm{x} 45 \mathrm{~cm}$.

Fertilizer levels had positive effect on seed cotton yield $\mathrm{kg} \mathrm{ha}{ }^{-1}$ and increased with increase in fertilizer levels upto 125per centof RDF. The maximum seed cotton yield $\mathrm{kg} \mathrm{ha}^{-1}$ (1094.31) was recorded with 125 per cent of RDF. Bhalerao and Gaikwad (2010) reported higher seed cotton yield with the application of 125 per cent of RDF.

In conclusion the seed cotton yield increased with increase in fertilizer level upto 125 per cent of RDF further increase in fertility had no significant effect on the seed cotton yield. Plant spacing had a positive effect on the seed cotton yield. Plant height and LAI negatively associated with plant spacing, plant height and LAI decrease with increase in plant spacings.

However, dry matter accumulation per plant increase with increase in plant spacing. Application of higher amount of fertilizer had positive effects on plant height, LAI and dry matter accumulation per plant, they increase with increase fertility.

\section{References}

Bhalerao, P.D. and Gaikwad, G.S. 2010. Productivity and profitability of Bt cotton (Gossypium hirsutum) under various plant geometry and fertilizer levels. Indian $\mathrm{J}$. Agron., 55(1): 60-63.

Bondada, B.R., Oosterhuis, D.M., Norman, R.J., Baker, W.H., 1996. Canopy photosynthesis, growth, yield, and boll $15 \mathrm{~N}$ accumulation under nitrogen stress in cotton. Crop Sci. 36, 127-133.

Boquet, D.J., Moser, E.B., Breitenbeck, G.A., 1993. Nitrogen effects on boll production of field-grown cotton. Agron. J. 85, 34-39.

Bridge, R.R., Meredith, W.R., Chism, J.F., 1973. Influence of planting method and plant population on cotton (Gossypium hirsutum). Agron. J. 65, 104-110.

Darawsheh, M.K., Khah, E.M., Aivalakis, G., Chachalis, D. and Sallaku, F., 2009.Cotton row spacing and plant density cropping systems I. Effects on accumulation and partitioning of dry mass and LAI.J. Food 
Agric. Environ, 7(3-4), pp. 258-261.

El-Shinnawy, A., Ghaly, F.M., 1985.Effect of plant density on growth and yield in two Upland cotton cultivars ( $G$. hirsutum L.).Agric. Res. Rev. Egypt 63, 109- 119.

Felix B.F., B.A. Roberts, R.L. Travis, D.W. Rains and R.B. Hutmacher. 2003. Response of irrigated acala and pima cotton to nitrogen fertilization growth, dry matter partitioning, andyield. Agron. J., 95:133-146.

Fritschi, F.B., Roberts, B.A., Travis, R.L., Rains, D.W. and Hutmacher, R.B., 2003. Response of irrigated Acala and Pima cotton to nitrogen fertilization: Growth, dry matter partitioning, and yield. Agronomy Journal, 95(1), pp.133-146.

Halemani, H.L., Hallikeri, S.S., 2002. Response of compact and early maturing cotton genotypes to plant population levels under rainfed conditions. J. Cotton Res. Dev. 16, 143-146.

Hou, Z., Li, P., Li, B., Gong, Z., Wang, Y., 2007. Effects of fertigation scheme on $\mathrm{N}$ uptake and $\mathrm{N}$ use efficiency in cotton. Plant Soil 290, 115-126.

Kaur, M. and Brar, A.S. 2005. Influence of different spacing on yield and yield attributes of cotton (Gossypium hirsutum L.). J. Cotton Res. Dev., 19(2): 197-199.

Kumar, M., Pannu, R.K., Nehra, D.S. and Dhaka, A.K. 2011. Effect of spacing and fertilizer on growth, yield and quality of different cotton genotypes. J. cotton Res. Dev., 25(2): 236-239.

Nehra, P.L. and Chandra, M. 2001. Performance of hirsutum cotton under different sowing dates and spacing. J. Cotton Res. Dev., 15(2): 147-150.

Nehra, P.L. and Kumawat, P.D. 2003. Response of hirsutum cotton varieties to spacing and nitrogen levels. J. Cotton Res. Dev., 17(1): 41-42.

Oosterhuis, D., 2001. Physiology and nutrition of high yielding cotton in the USA. Informac õesAgronômicas Piracicaba 95, 18-24.

Paslawar, A.N., Deotalu, A.S., Deshmukh, S.B. and Bhongle, S.A. 2014.Productivity of arboreum cotton hybrids and quality as influenced by plant spacing and fertilizer management. Periodic Res., 3(1): 14-16.

Prasad, H., Nehra, P.L., Gothwal, D.K. and Singh, H. 2000. Effect of date of sowing and spacing on seed cotton yield. J. Cotton Res. Dev., 14(2): 232-234.

Ram, M. and Giri, A.N. 2006.Response of newly released cotton (Gossypium hirsutum) varieties to plant densities and fertilizer levels. J. Cotton Res. Dev., 20(1): 85-86.

Sagarka, B.S., Malavia, D.D., Solan, R.M., Kachot, N.A. and Dabhi, B.M. 2002. Effect of irrigation method and nitrogen on yield and quality of winter cotton (Gossypium hirsutum). Indian J. Agron., 47(4): 544-549.

Tayade, A.S., Raju, A.R. \&Dhoble, M.V. 2011. Studies on correlation and path coefficient analysis in $B t$ and non $B t$ cotton hybrids (Gossypium hirsutum L.). J. Cotton Res. Dev., 25(2): 147-151.

Thokale, J.G., Raut, R.S. and Mehetre, S.S. 2004. Effect of fertilizers and spacing on yield parameters of interspecific hybrid Phule492 under summer irrigated conditions. J. Cotton Res. Dev., 19(1): 167-168.

Wullschleger, S.D., Oosterhuis, D.M., 1990.Canopy development and photosynthesis of cotton as influenced by nitrogen nutrition. J. Plant Nutr. 13, 11411154.

\section{How to cite this article:}

Amit Singh, M. L. Khichar, Ram Niwas, Sagar Kumar, Divesh, Mamta and Rahul. 2020. Influence of Different Levels of Fertility and Plant Geometry on Growth and Yield of $B t$ Cotton. Int.J.Curr.Microbiol.App.Sci. 9(09): 377-383. doi: https://doi.org/10.20546/ijcmas.2020.909.047 